\title{
PENERAPAN AUGMENTED REALITY PADA MEDIA PEMBELAJARAN PEMINTALAN SERAT BUATAN BERBASIS ANDROID (studi kasus : SMK Texmaco Semarang)
}

Setiyo Prihatmoko ${ }^{1}$, Fajar Kurniawan ${ }^{2}$

${ }^{1}$ Program Studi Desain Grafis Universitas Sains dan Teknologi Komputer

Email : setiyo@stekom.ac.id

${ }^{2}$ Program Studi Desain Grafis Universitas Sains dan Teknologi Komputer

\section{ARTICLE INFO}

Article history:

Received 25 November 2020

Received in revised form 28 November 2020

Accepted 26 December 2020

Available online 28 Desember 2020

\section{ABSTRACT}

This research produces Artificial Fiber Spinning Learning Media that applies Augmented Reality (AR) for Class XI Students of TPSB SMK Texmaco Semarang as a learning aid. so that it can be used as a modern, effective, and interactive learning medium. This application was made with the aim of completing the limitations of depicting objects in existing learning media, helping students to more easily learn the material, improving student learning outcomes, and increasing the variety of media in learning. This study uses the Research and Development $(\mathrm{RnD})$ method, using 6 out of 10 research stages, namely potentials and problems, data collection, product design, design validation, design improvement and product testing. The final result of making this learning media is an application in the format android application, used on every android-based mobile phone. The validity value of the media expert obtained a value of 3.2 which was declared feasible, the results of the material expert validation test obtained a value of 3.6 which was declared very feasible, and was able to increase the average value of the artificial fiber spinning subject class XI TPSB SMK Texmaco Semarang which Initially $61.5 \%$ with 17 students who had not reached the KKM to $80.5 \%$ with 4 students who had not reached the KKM.

Keywords: Learning media, Augmented Reality,Android 



\section{PENDAHULUAN}

Pesatnya perkembangan Teknologi Informasi dan Komunikasi (TIK) telah mempengaruhi banyak bidang kehidupan manusia. Berbagai perangkat canggih TIK yang ada, berpengaruh besar terhadap bagaimana manusia menjalani hidupnya. Bidang kehidupan yang tak luput dari pengaruhnya itu di antaranya adalah pendidikan. Pendidikan dan lebih spesifiknya pembelajaran sekarang ini banyak dipengaruhi perkembangan TIK, bukan hanya dari berbagai peralatan yang digunakan dan kemudahan-kemudahan yang ditawarkannya, melainkan berpengaruh terhadap berbagai aspek pedagogis yang menyertainya [2]

Keberadaan ponsel pintar (smartphone), tablet, aplikasi dan media sosial contohnya, kini merupakan hal yang tidak terpisahkan dari keseharian. Perubahan-perubahan itu telah mengubah pandangan dan praktik-praktik pembelajaran di sekolah. Pembelajaran yang berpusat pada guru dengan menggunakan media terbatas telah bergeser kepada pembelajaran yang berpusat pada siswa.

Sisi lain di era globalisasi saat ini, siswa menghadapi sejumlah tantangan dalam cara mereka memperoleh informasi. Perkembangan teknologi informasi dan komunikasi telah mengubah gaya belajar siswa. Belajar dengan hanya mengunakan metode yang berpusat pada guru sudah tidak cocok lagi diterapkan pada era teknologi dengan serbuan informasi yang tidak terbatas saat ini. Siswa tidak akan betah jika selama berjam-jam hanya mendengarkan ceramah guru. Kombinasi pendekatan pembelajaran yang beragam dengan memanfaatkan perangkat teknologi informasi perlu untuk mengubah pembelajaran siswa, dari pembelajaran pasif ke pembelajaran aktif, pembelajaran tergantung pada guru ke belajar mandiri, yang dapat mengeksplorasi keterampilan dan kolaborasi dalam sebuah kerja sama yang menguntungkan.

Pemanfaatan teknologi smartphone dalam bidang pendidikan salah satunya digunakan sebagai media pembelajaran. Media pembelajaran adalah segala sesuatu yang menyangkut software dan hardware yang dapat digunakan untuk menyampaikan isi materi ajar dari sumber pembelajaran ke peserta didik (individu atau kelompok). Sanaky (2013) dalam Suryani, Setiawan, \& Putria, (2018) menyatakan bahwa media pembelajaran adalah sebuah alat yang berfungsi dan dapat digunakan untuk menyampaikan pesan pembelajaran. [11]

Berdasarkan pengamatan yang dilakukan di SMK Texmaco Semarang kelas XI Teknik Pemintalan Serat Buatan (TPSB), pada saat kegiatan belajar mengajar, guru memberikan tugas kepada siswa untuk mencatat semua materi yang disajikan pada modul pembelajaran, dan cara penyampaian materi pelajaran dengan metode ceramah. Hal ini cenderung membuat siswa merasa bosan yang pada akhirnya menjadi pasif dalam menerima pelajaran, dapat dilihat dari sikap siswa yang lebih memilih berbicara dengan temannya, memainkan smartphone tanpa sepengetahuan guru, bahkan ada siswa yang tidur pada saat guru sedang tidak memperhatikan siswanya, hanya beberapa siswa saja yang mengikuti pembelajaran dengan baik.

Cara mengajar guru yang pasif, seperti hanya memberikan catatan atau hanya mendikte dengan sedikit memberikan penjelasan dapat membuat minat belajar siswa terhadap pelajaran akan berkurang, karena siswa tidak melihat hal yang menarik untuk disimak dari proses belajar mengajar tersebut, sehingga menyebabkan rasa bosan dan mengantuk, maka siswa tidak akan berkonsentrasi pada proses pembelajaran.

Hasil pengamatan pada media pembelajaran cetak dan modul e-book yang digunakan, materi proses pemintalan serat digambarkan secara dua dimensi. Berdasarkan hasil wawancara dengan Ibu. Istinharoh, selaku guru kompetensi keahlian teknik pemintalan serat buatan, beliau mengatakan bahwa: "gambar yang ada pada buku tidaklah cukup untuk menggambarkan objek yang saya inginkan, sehingga perlu media tambahan untuk membelajarkannya kepada siswa."

Kelas XI TPSB memiliki 2 mata pelajaran produktif yaitu pemintalan serat buatan dan polimerisasi. Berdasarkan data di atas dapat dilihat bahwa nilai rata-rata mata pelajaran produktif kelas XI TPSB SMK Texmaco Semarang dari tahun ajaran 2016/2017, 2017/2018, 
2018/2019 nilai rata-rata yang paling rendah adalah nilai mata pelajaran pemintalan serat buatan yaitu sebesar 73,6 dibandingkan dengan nilai mata pelajaran polimerisasi yaitu sebesar 77,6.

Menyikapi hal tersebut, untuk mengoptimalkan hasil belajar dan minat belajar siswa, juga melengkapi keterbatasan penggambaran objek pada materi pemintalan serat buatan, cara yang tepat perlu media yang modern. Dalam hal ini smartphone sebagai pendukung penyampaian materi dan dikemas melalui media aplikasi dengan menggunakan teknologi Augmented Reality (AR).

Saat ini teknologi AR juga telah dikembangkan pada smartphone Android. Android merupakan platform lengkap mulai dari sistem operasi, aplikasi, tool developing, market, dukungan vendor industri mobile, bahkan dukungan dari komunitas open system, tentu merupakan keunggulan yang tidak dimiliki oleh platform lain [5]

Data dari angket tentang penggunaan smartphone dengan jumlah angket 20 lembar yang diberikan pada siswa kelas XI TPSB SMK Texmaco Semarang pada tanggal 17 April 2019 menyatakan bahwa sebanyak 18 angket atau 90\% siswa memiliki smartphone berbasis Android.

Mengembangkan media pembelajaran dengan didukung oleh perangkat yang memadai seperti smartphone Android dan teknologi augmented reality yang dikombinasikan secara langsung dengan materi dari buku cetak, obyek dapat divisualisasikan melalui permodelan virtual di atas materi buku cetak tersebut, sehingga dalam proses pembelajaran menjadi lebih interaktif.

\section{DASAR TEORI \\ Belajar}

Warsita (2008) belajar (learning) adalah suatu proses kompleks yang terjadi pada semua orang dan berlangsung seumur hidup. Belajar dapat terjadi di rumah, di sekolah, di tempat kerja, di tempat ibadah, dan di masyarakat, serta berlangsung dengan cara apa saja, dari apa, dan siapa saja. Kemampuan orang untuk belajar ini merupakan salah satu ciri penting yang membedakan manusia dengan makhluk yang lain.[3]

\section{Pembelajaran}

Warsita (2008) Pembelajaran adalah suatu usaha untuk membuat peserta didik belajar atau suatu kegiatan untuk membelajarkan peserta didik. Pembelajaran merupakan upaya menciptakan kondisi agar terjadi kegiatan belajar. Pengertian lain, pembelajaran adalah usahausaha yang terencana dalam memanipulasi sumber-sumber belajar agar terjadi proses belajar dalam diri peserta didik.[3]

\section{Media}

Kata media berasal dari bahasa latin medius yang secara harfiah berarti 'tengah', 'perantara', atau 'pengantar'. Secara lebih khusus, pengertian media dalam proses belajar mengajar cenderung diartikan sebagai alat-alat grafis, photografis, atau elektronik untuk menangkap, memproses, dan menyusun kembali informasi visual atau verbal [1]

\section{Media Pembelajaran}

Media pembelajaran adalah segala sesuatu yang menyangkut software dan hardware yang dapat digunakan untuk menyampaikan isi materi ajar dari sumber pembelajaran ke peserta didik (individu atau kelompok), yang dapat merangsang pikiran, perasaan, perhatian, dan minat pembelajar sedemikian rupa sehingga proses pembelajaran (di dalam/ di luar kelas) menjadi lebih efektif [8].

\section{Augmented Reality}

Secara umum, augmented reality (AR) adalah penggabungan antara objek virtual dengan objek nyata. Sebagai contoh, adalah saat stasiun televisi, menyiarkan pertandingan sepak bola, terdapat objek virtual, tentang skor pertandingan yang sedang berlangsung. Augmented reality atau dalam bahasa Indonesia (realitas tambahan) adalah sebuah teknik yang JURNAL ILMIAH KOMPUTER GRAFIS Vol. 13, No. 1, Juli 2020: 1-8 
menggabungkan benda maya dua dimensi maupun tiga dimensi ke dalam sebuah lingkungan nyata lalu memproyeksikan benda-benda maya tersebut dalam waktu nyata (Pamoedji, Maryuni, \& Sanjaya, 2017). Menurut Ronald T. Azuma (1997), augmented reality adalah menggabungkan dunia nyata dan virtual, bersifat interaktif secara real time, dan merupakan animasi 3D. [10]

Augmented Reality (AR) merupakan kebalikan dari Virtual Reality (VR), dimana VR menambahkan obyek nyata didalam dunia maya, sedangkan AR adalah menambahkan obyek maya ke dalam dunia nyata. [4]

\section{Android}

Android adalah sistem operasi berbasis Linux yang dirancang untuk perangkat bergerak layar sentuh seperti telepon pintar dan komputer tablet. Android adalah nama dari salah satu varian sistem operasi yang berbasis kernel Linux yang khusus diperuntukan untuk perangkat telepon seluler dengan fitur layar sentuh (touchscreen), contohnya seperti smartphone serta tablet. [5]

\section{Pemintalan Serat Buatan}

Pemintalan Serat Buatan adalah salah satu mata pelajaran produktif Sekolah Menengah Kejuruan kompetensi keahlian Teknik Pemintalan Serat Buatan (TPSB) di SMK Texmaco Semarang. Pemintalan serat buatan ini merupakan mata pelajaran yang sangat penting bagi siswa kelas XI TPSB sebelum melaksanakan Praktik Kerja Lapangan (PKL) di dunia Industri.

\section{METODE PENELITIAN}

Jenis Penelitian

Jenis penelitian ini adalah penelitian dan pengembangan (Research and Development). Metode Penelitian dan Pengembangan adalah metodepenelitian yang digunakan untuk menghasilkan produk tertentu, dan mengujikeefektifan produk tersebut. [12]

MetodeResearch and Development (R\&D) Sugiyono mempunyai 10 langkah sebagai berikut:

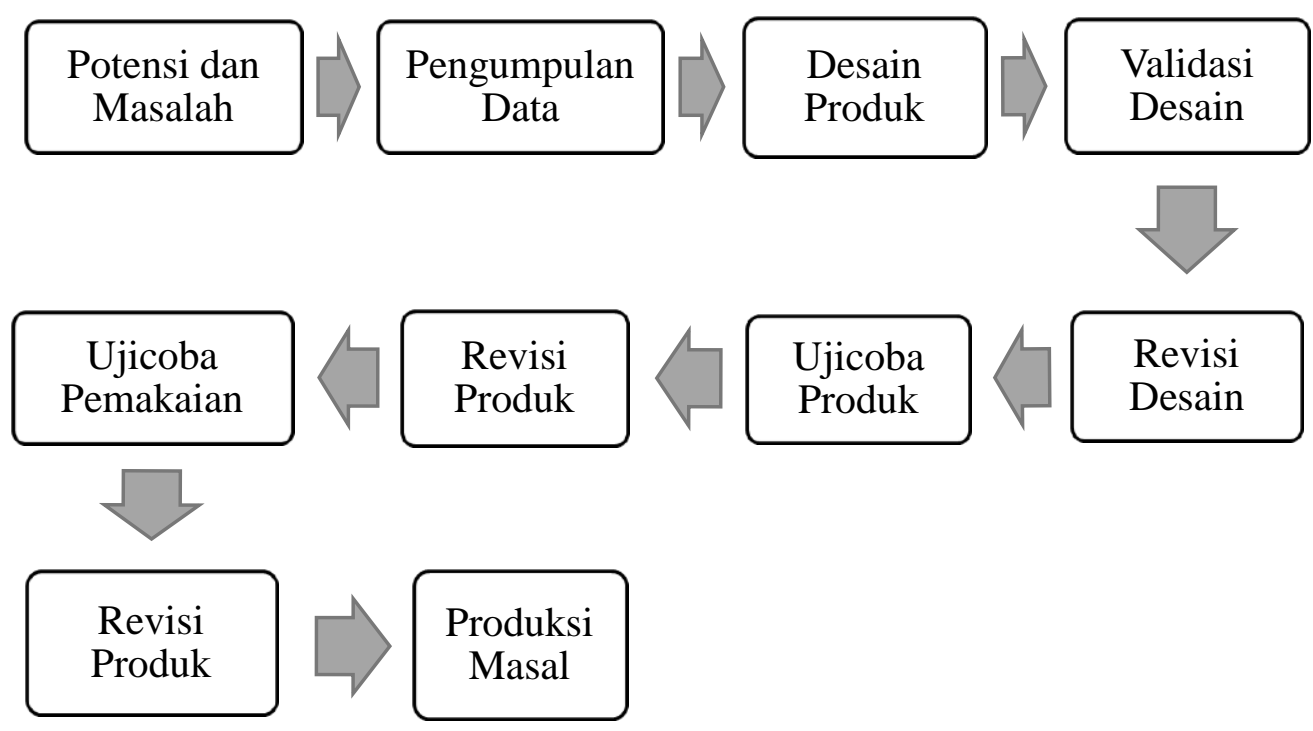

Gambar 1. Langkah-Langkah penggunaan Metode Research and Development (R\&D)

1. Potensi dan masalah

Penelitian ini dimulai dari adanya potensi atau masalah. Potensi merupakan segala sesuatu atau kemampuan yang mempunyai kemungkinan untuk dikembangkan agar mendapat suatu nilai tambah pada produk yang diteliti. Masalah akan timbul ketika terjadi 
penyimpangan antara suatu hal yang diharapkan dengan realita yang terjadi. Masalah juga dapat dijadikan sebagai potensi, apabila dapat mendayagunakannya. Potensi dan masalah yang dikemukakan dalam penelitian harus disertai dengan data empiris.

2. Pengumpulan Data

Setelah potensi dan masalah dapat ditunjukkan secara faktual, maka selanjutnya perlu dikumpulkan berbagai informasi yang dapat digunakan sebagai bahan untuk perencanaan produk tertentu agar dapat menyelesaikan masalah tersebut.

3. Desain Produk

Produk yang dihasilkan dalam penelitian Research and Development bermacammacam. Desain produk ini harus diwujudkan dalam bentuk gambar atau bagan, sehingga dapat digunakan sebagai pegangan untuk menilai dan membuatnya. Desain produk harus dilengkapi dengan penjelasan mengenai bahan-bahan dan alat yang digunakan untuk mengerjakan produk tersebut. Hasil akhir dari kegiatan ini adalah berupa desain sistem yaitu Rancangan Sistem Kerja Baru. Desain ini masih bersifat hipotesa karena efektifitas produk belum terbukti dan diujikan di lapangan.

4. Validasi Desain

Validasi desain merupakan proses kegiatan untuk menilai secara rasional apakah rancangan produk akan lebih efektif dari yang lama atau tidak. Dikatakan secara rasional, karena validasi ini bersifat penilaian berdasarkan pemikiran rasional, belum fakta lapangan.

5. Perbaikan Desain

Setelah desain produk divalidasi dengan pakar dan para ahli lainnya, maka akan dapat diidentifikasi kelemahannya. Kelemahan tersebut selanjutnya dicoba untuk dikurangi dengan cara memperbaiki desain. Dalam hal ini peneliti yang bertugas untuk memperbaiki desain produk yang dihasilkan.

6. Uji Coba Produk

Uji coba produk dilakukan setelah desain produk selesai diperbaiki. Pengujian ini dilakukan untuk mendapatkan informasi apakah sistem kerja yang baru dihasilkan lebih efektif dan efisien dibandingkan dengan produk lama.

7. Revisi Produk

Revisi produk dilakukan setelah desain produk selesai duji coba. Kekurangan pada yang tampak pada hasil uji coba akan diminimalisir. Langkah revisi ini dilakukan untuk memperbaiki produk yang kurang efektif maupun efisien sehingga didapatkan hasil produk yang maksimal.

8. Uji Coba Pemakaian

Setelah pengujian dan revisi terhadap produk, maka selanjutnya produk tersebut diterapkan dalam kondisi nyata untuk lingkup yang luas. Dalam uji coba pemakaian produk tersebut tetap harus dinilai kekurangan atau hambatan yang muncul untuk perbaikan lebih lanjut.

9. Revisi Produk

Revisi produk dilakukan apabila dalam uji coba pemakaian terdapat kekurangan dan kelemahan. Dalam uji coba pemakaian sebaiknya pembuat produk selalu mengevaluasi bagaimana kinerja produk untuk mengetahui kelemahan-kelemahan yang ada, sehingga dapat digunakan untuk penyempurnaan produk.

10. Pembuatan Produk Masal

Pembuatan produk masal ini dilakukan apabila produk yang telah di uji coba dinyatakan efektif dan layak untuk di produksi masal.

\section{Ruang Lingkup Penelitian}

Pengertian dari ruang lingkup penelitian adalah batasan. Ruang lingkup juga dapat dikemukakan pada bagian variabel-variabel yang diteliti, populasi atau subjek penelitian, dan

\section{JURNAL ILMIAH KOMPUTER GRAFIS Vol. 13, No. 1, Juli 2020: 1-8}


lokasi penelitian. Sehingga penulis menentukan ruang lingkup penelitian di dalam SMK Texmaco semarang yaitu pada kelas XI TPSB.

\section{Variabel Penelitian}

Ada dua variabel dalam penelitian ini antara lain aspek desain pembelajaran, dan aspek desain komunikasi visual.

\section{Pengambilan Data}

Penelitian dan pegembangan ini menggunakan beberapa macam metode dalam mengumpulkan data yaitu wawancara, observasi, dan kuesioner.

Rancangan pengembangan dengan desain R\&D dari Sugiyono mempunyai 10 langkah yang bertujuan untuk mengembangkan dan memvalidasi produk, namun pada penelitian ini hanya akan diterapkan 6 langkah awal dalam pengembangan produk, yakni sebagai berikut:

\section{Potensi dan masalah}

Pada penelitian ini, potensi yang dimiliki SMK Texmaco Semarang khususnya pada kelas XI TPSB yakni dari angket tentang penggunaan smartphone dengan jumlah angket 20 lembar yang diberikan pada siswa pada tanggal 17 April 2019 yang menyatakan bahwa sebanyak 18 angket atau 90\% siswa memiliki smartphone berbasis Android.

Masalah yang muncul yakni keterbatasan penggambaran objek pada materi pembelajaran, kurangnya variasi pada media pembelajaran yang digunakan, kurangnya minat belajar siswa dan nilai akhir siswa pada mata pelajaran produktif khususnya pada materi pemintalan serat buatan dengan rata-rata nilai materi yang dicapai belum memenuhi Kriteria Ketuntasan Minimal (KKM) yang ditetapkan yaitu 75.

Dari beberapa potensi dan masalah tersebut menimbulkan gagasan bagaimana membuat media pembelajaran yang valid dan efektif untuk siswa Kelas XI TPSB SMK Texmaco Semarang.

2. Pengumpulan Data

Permasalahan yang timbul di SMK Texmaco Semarang, diperoleh dari informasi melalui wawancara dengan narasumber, melakukan observasi pada media dan kegiatan pembelajaran di kelas, 20 angket yang diberikan kepada siswa kelas XI TPSB dengan pertanyaan tentang penggunaan smartphone, dan informasi tentang daftar nilai rata-rata kelas XI TPSB tahun pelajaran 2016-2018 dari bagian kurikulum.

\section{Desain Produk}

Pada tahap ini dilakukan pembuatan desain produk penerapan Augmented Reality pada media pembelajaran pemintalan serat buatan berbasis Android. Langkah-langkah yang dilakukan yaitu:

a. Membuat flowchart aplikasi dan storyboard. Flowchart dan storyboard dibuat dengan tujuan mempermudah dalam pembuatan media dan untuk menentukan tahap pengembangan selanjutnya agar bagian-bagian dari media pembelajaran dapat tersusun dengan baik.

b. Storyboard dibuat dengan cara menggambar sketsa di atas kertas, sketsa yang telah selesai dibuat lalu digambar ulang menggunakan komputer.

c. Storyboard lalu dijadikan acuan membuat layout. Layout dibuat dengan memperhatikan aspek warna dan komposisi desain.

Storyboard merupakan deskripsi gambaran dalam pembuatan media pembelajaran yang dibuat untuk memudahkan proses pembuatan sebuah produk. Adapun storyboard sebagai berikut: 
Tabel 3.1Storyboard

\begin{tabular}{|c|c|c|c|}
\hline No & Deskripsi & Desain & Musik dan Navigasi \\
\hline 1 & \begin{tabular}{lr}
\multicolumn{2}{l}{ Scene 1} \\
Tampilan & \\
aplikasi & yang \\
berfungsi & sebagai \\
timer & untuk \\
menuju ke & menu \\
utama. &
\end{tabular} & logo & $\begin{array}{l}\text { Musik: } \\
\text { Suara Narator }\end{array}$ \\
\hline 2 & $\begin{array}{l}\text { Scene } 2 \\
\text { Tampilan Menu } \\
\text { berisi menu utama } \\
\text { yaitu AR Materi, } \\
\text { AR Objek, AR } \\
\text { Kuis. }\end{array}$ & \begin{tabular}{|c|} 
MENU \\
AR MATERI \\
AR OBJEK \\
AR KUIS
\end{tabular} & $\begin{array}{l}\text { Musik: } \\
\text { Musik Latar Belakang } \\
\text { Navigasi: } \\
\text { 1) Tombol Menu lain-lain } \\
\text { 2) Tombol Musik } \\
\text { 3) Tombol Profil } \\
\text { 4) Tombol Referensi } \\
\text { 5) Tombol Petunjuk } \\
\text { 6) Tombol Keluar }\end{array}$ \\
\hline 3 & $\begin{array}{l}\text { Scene } 3 \\
\text { Tampilan Panduan } \\
\text { sebelum menuju ke } \\
\text { menu AR Materi. } \\
\text { Terdapat gambar- } \\
\text { gambar panduan } \\
\text { penggunaan AR } \\
\text { Materi. }\end{array}$ & $\begin{array}{l}\text { Kambali } \\
\text { Panduan }\end{array}$ & $\begin{array}{l}\text { Navigasi: } \\
\text { 1) Tombol Kembali } \\
\text { 2) Tombol Mulai }\end{array}$ \\
\hline 4 & $\begin{array}{l}\text { Scene } 4 \\
\text { Tampilan AR } \\
\text { Materi. } \\
\text { Terdiri dari panel } \\
\text { latar belakang, 2 } \\
\text { materi yaitu } \\
\text { pemintalan kering } \\
\text { dan pemintalan } \\
\text { basah. }\end{array}$ & AR MATERI & $\begin{array}{l}\text { Navigasi: } \\
\text { 1) Tombol Kembali } \\
\text { 2) Tombol Tutup Panel }\end{array}$ \\
\hline
\end{tabular}

JURNAL ILMIAH KOMPUTER GRAFIS Vol. 13, No. 1, Juli 2020: $1-8$ 


\begin{tabular}{|c|c|c|c|}
\hline 5 & $\begin{array}{l}\text { Scene } 5 \\
\text { Tampilan AR } \\
\text { Video terdapat } \\
\text { video animasi } \\
\text { tentang pembuatan } \\
\text { benang }\end{array}$ & 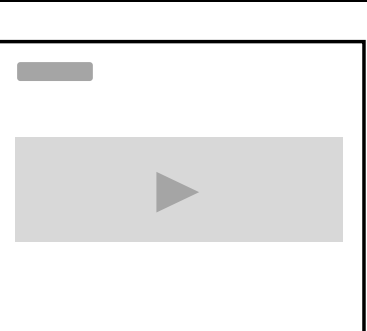 & $\begin{array}{l}\text { Musik: } \\
\text { Suara Narator } \\
\text { Navigasi: } \\
\text { Tombol Kembali }\end{array}$ \\
\hline 6 & $\begin{array}{l}\text { Scene } 6 \\
\text { Panduan sebelum } \\
\text { menuju ke menu } \\
\text { AR Objek. } \\
\text { Terdapat gambar- } \\
\text { gambar panduan } \\
\text { penggunaan AR } \\
\text { Objek. }\end{array}$ & Kambai & $\begin{array}{l}\text { Navigasi: } \\
\text { 1) Tombol Kembali } \\
\text { 2) Tombol Mulai }\end{array}$ \\
\hline 7 & $\begin{array}{l}\text { Scene } 7 \\
\text { Tampilan AR } \\
\text { Objek berisi objek } \\
\text { 3D proses } \\
\text { pembentukan } \\
\text { polimer pada } \\
\text { pemintalan buatan }\end{array}$ & 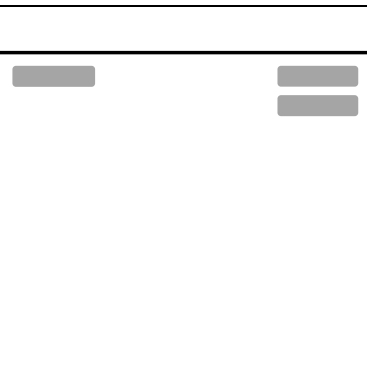 & $\begin{array}{l}\text { Musik: } \\
\text { Suara Narator } \\
\text { Navigasi: } \\
\text { 1) Tombol Kembali } \\
\text { 2) Tombol Informasi } \\
\text { 3) Tombol Narasi }\end{array}$ \\
\hline 8 & $\begin{array}{l}\text { Scene } 8 \\
\text { Panduan sebelum } \\
\text { menuju ke menu } \\
\text { AR Kuis. } \\
\text { Terdapat gambar- } \\
\text { gambar panduan } \\
\text { penggunaan AR } \\
\text { Kuis. }\end{array}$ & Panduan & $\begin{array}{l}\text { Navigasi: } \\
\text { 1) Tombol Kembali } \\
\text { 2) Tombol Mulai }\end{array}$ \\
\hline
\end{tabular}




\begin{tabular}{|c|c|c|c|}
\hline 9 & $\begin{array}{l}\text { Scene 9 } \\
\text { Tampilan AR } \\
\text { Kuis. } \\
\text { Terdiri dari panel } \\
\text { background, teks } \\
\text { jumlah pertanyaan, } \\
\text { teks pertanyaan, } \\
\text { teks koreksi } \\
\text { jawaban. } \\
\text { Tampilan } \\
\text { nilai. hasil } \\
\text { Terdiri dari panel } \\
\text { background, teks } \\
\text { nama siswa, teks } \\
\text { skor, input field } \\
\text { nama siswa. }\end{array}$ & $\begin{array}{l}\text { Nama } \\
\text { SKOR: } \\
\text { XXX }\end{array}$ & $\begin{array}{l}\text { Musik: } \\
\text { Musik Latar Belakang } \\
\text { Navigasi: } \\
\text { 1) Tombol Kembali } \\
\text { 2) Tombol Jawaban } \\
\text { 3) Tombol Enter Nama }\end{array}$ \\
\hline
\end{tabular}

Berikut adalah flowchart Penerapan Augmented Reality pada Media Pembelajaran berbasis Android:

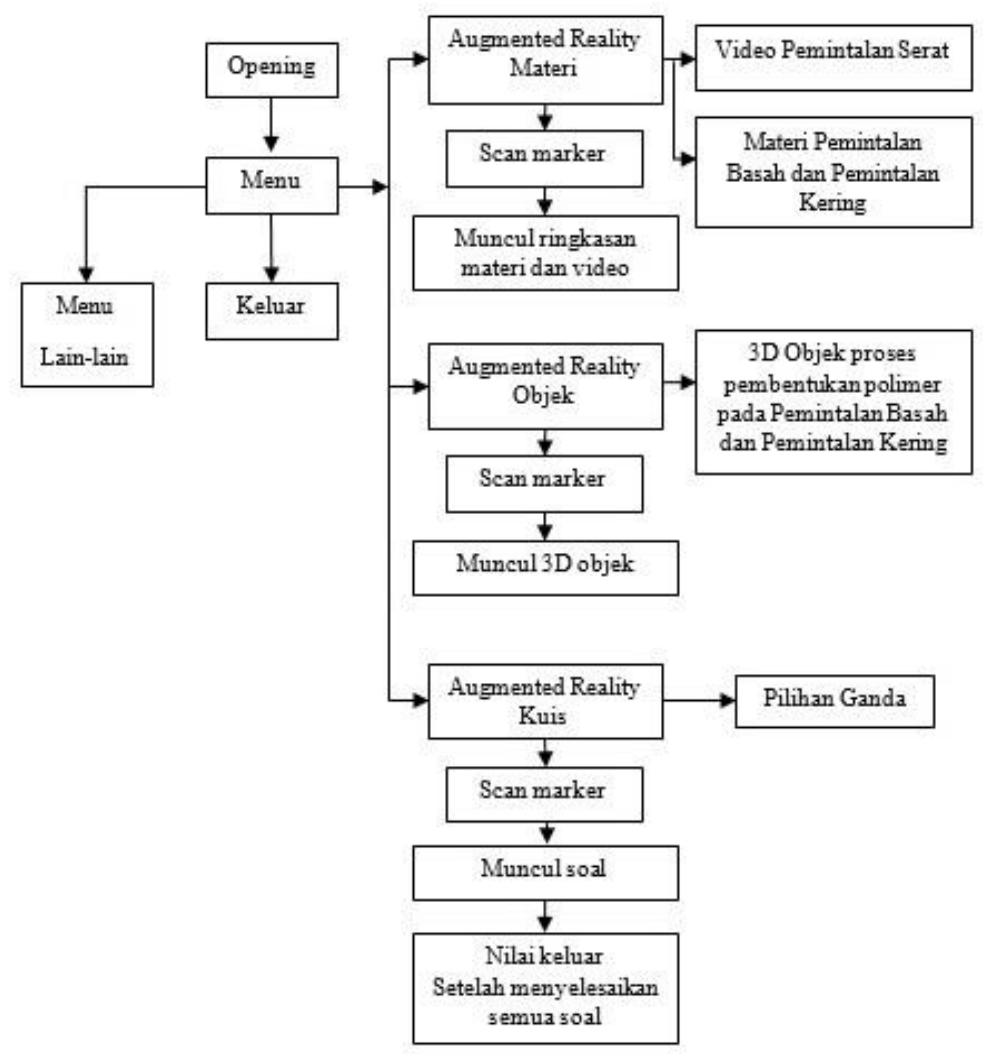

Gambar 2. Flowchart Aplikasi

JURNAL ILMIAH KOMPUTER GRAFIS Vol. 13, No. 1, Juli 2020: 1-8 
4. Validasi Desain

Validasi desain merupakan salah satu proses pengembangan yang dilakukan guna mengetahui tingkat keefektifan produk tersebut. Uji validitas menghadirkan para ahli materi serta ahli media dengan penilaian menggunakan angket.

Perhitungan validasi dapat diterapkan dengan rumus:

$$
\bar{X}=\frac{\sum \mathrm{x}}{\mathrm{n}}
$$

Keterangan:

$\bar{X} \quad=$ nilai rata-rata

$\Sigma \mathrm{x} \quad=$ jumlah total nilai validasi

$\mathrm{n} \quad=$ jumlah validator

Berdasarkan penjabaran rumus di atas, penentuan nilai hasil rata-rata dengan menggunakan skala kriteria validitas. Skala kriteria dimulai dari skala 1 yang terendah dan skala 4 sebagai skala tertinggi. Selanjutnya skala tersebut dikelompokkan ke dalam 4 kelas dengan rentangan yang sama. Penentuan rentangan masing-masing kelas dilakukan dengan menghitung nilai skala tertinggi dikurangi selisih nilai skala. Selisih nilai skala yakni 0,75.

Tabel 1. Kriteria Kevalidan

\begin{tabular}{|l|l|}
\hline Nilai & Kriteria Kevalidan \\
\hline $3,26-4,00$ & Sangat Valid \\
\hline $2,51-3,25$ & Valid \\
\hline $1,76-2,50$ & Kurang Valid (revisi) \\
\hline $1,00-1,75$ & $\begin{array}{l}\text { Tidak Valid (revisi } \\
\text { total) }\end{array}$ \\
\hline
\end{tabular}

5. Perbaikan Desain

Perbaikan desain dilakukan apabila, penilaian dari para ahli menunjukkan bahwa desain yang dirancang oleh peneliti dianggap kurang valid. Sehingga peneliti wajib memperbaiki (revisi) rancangan desain hingga rancangan tersebut benar-benar valid dan layak untuk diterapkan.

6. Ujicoba Produk

Uji coba produk dilakukan di SMK Texmaco Semarang kelas XI TPSB dengan jumlah subyek uji coba sebanyak 20 siswa. Uji coba ini dimaksudkan sebagai penetapan tingkat keefektifan, efisiensi, serta daya tarik produk yang dihasilkan. Dalam hal ini mencakup beberapa bagian dalam uji coba, diantaranya:

1. Desain Uji Coba

Desain uji coba dilakukan dengan pengelompokan data nilai yang diperoleh dari pembagian angket kepada para ahli desain dan ahli materi. Pengisian angket terdapat beberapa poin tentang kelayakan desain produk serta para ahli diwajibkan memberikan saran dan kritik. Hal ini bertujuan agar peneliti dapat mengetahui apakah desain produknya layak dan dapat diuji validasi selanjutnya atau disebut validasi empiris. Validasi empiris dilakukan dengan cara membandingkan kriteria yang ada pada instrumen dengan fakta-fakta empiris yang terjadi dilapangan. Namun pada penelitian ini tidak dilakukan validasi empiris karena 
keterbatasan waktu serta biaya, sehingga pengujian hanya dilakukan sampai validasi oleh ahli (uji ahli) dan kelompok kecil.

2. Subyek Uji Coba

Pengujian subyek pada terhadap produk pengembangan yang akan diteliti ini dilakukan dengan menghadirkan validator-validator. Validator ini terbagi atas kelompok ahli, yakni ahli materi, ahli multimedia, serta 20 siswa berlaku sebagai kelompok kecil.

3. Jenis Data

Data yang digunakan pada penelitian ini yakni data kuantitatif dan data kualitatif.

a. Data kualitatif merupakan suatu jenis data yang digunakan untuk mengukur suatu produk dalam penelitian berdasarkan kualitas produk. Data kualitatif yang digunakan dalam penelitian ini yaitu:
1) Sangat Valid (SV)
2) Valid (V)
3) Kurang Valid (KV)
4) Tidak Valid (TV)

b. Data kuantitatif merupakan suatu jenis data yang digunakan untuk mengukur suatu produk dalam penelitian berdasarkan skor penilaian produk. Data kuantitatif yang digunakan dalam penelitian ini yaitu:

1) Sangat Valid (SV) dengan Skor 4

2) Valid (V) dengan Skor 3

3) Kurang Valid (KV) dengan Skor 2

4) Tidak Valid (TV) dengan Skor 1

4. Instrumen Pengumpulan Data

Dalam hal ini penulis menggunakan instrumen penelitian berupa angket yang dibedakan menjadi tiga macam yakni Angket untuk validasi ahli media pembelajaran, Angket untuk validasi ahli materi pembelajaran, Angket untuk validasi user.

5. Teknik Analisis Data

Dalam penelitian dan pengembangan ini digunakan dua teknik analisis data, yaitu: teknik analisis deskriptif kualitatif dan analisis deskriptif kuantitatif. Data kualitatif berupa komentar dan saran perbaikan produk dari ahli media pembelajaran dan ahli materi pembelajaran bidang studi yang nantinya akan dideskriptifkan secara deskriftif kualitatif untuk merevisi produk yang dikembangkan. Sedangkan data kuantitatif yaitu data berupa skor penilaian ahli media pembelajaran, ahli materi pembelajaran bidang studi yang berupa pengisian angket, adapun tujuan pengisian angket adalah untuk mengevaluasi media pembelajaran yang dibuat.

Data yang terkumpul dianalisis dengan teknik analisis deskriptif kuantitatif yang diungkapkan dalam distribusi skor dan persentase terhadap kategori skala penilaian yang telah ditentukan. Setelah penyajian dalam bentuk persentase, langkah selanjutnya mendeskriptifkan dan mengambil kesimpulan tentang masing-masing indikator.

Kesesuaian aspek dalam pengembangan bahan ajar dan media pembelajaran dapat menggunakan tabel berikut:

Tabel 2 Skala Presentase

\begin{tabular}{|l|l|}
\hline $\begin{array}{l}\text { Persentase } \\
\text { pencapaian }\end{array}$ & Interpretasi \\
\hline $76-100 \%$ & layak \\
\hline $56-75 \%$ & cukup layak \\
\hline $40-55 \%$ & kurang layak \\
\hline
\end{tabular}

JURNAL ILMIAH KOMPUTER GRAFIS Vol. 13, No. 1, Juli $2020: 1-8$ 


$$
\begin{array}{|l|l}
\hline 0-39 \% & \text { tidak layak } \\
\hline
\end{array}
$$

Pada tabel di atas disebutkan presentase pencapaian, skala nilai, dan interprestasi. Untuk mengetahui kelayakan digunakan tabel diatas sebagai acuan penilaian data yang dihasilkan dari validasi ahli media, ahli materi dan uji kelompok kecil serta uji coba kelompok besar.

\section{HASIL DAN PEMBAHASAN Hasil Penelitian}

Media pembelajaran pemintalan serat buatan merupakan salah satu sarana untuk mutu pendidikan kelas XI TPSB SMK Texmaco Semarang dengan memanfaatkan perkembangan teknologi saat ini yaitu augmented reality. Penerapan augmented reality pada media pembelajaran ini pada akhirnya dapat meningkatkan semangat belajar dan mampu meningkatkan prestasi belajar siswa.

Tahap awal penelitian yaitu penetapan jenismedia pembelajaran yang diterapkan pada SMK Texmaco Semarang, kemudian dilakukan observasi untuk mengetahui permasalahan yang terjadi pada lokasi. Pengambilan data dilakukan agar dapat mengetahui permasalahanpermasalahan secara akurat yang terjadi di lapangan. Data tersebut selanjutnya digunakan sebagai landasan perancangan dan pengembangan media pembelajaran yang akan dibuat. Hasil data yang diperoleh menunjukkan bahwa kurang maksimalnya nilai mata pelajaran produktif teknik pemintalan serat buatan pada materi pemintalan serat buatan. Hasil wawancara juga diperoleh beberapa konsep yang akan diterapkan pada media pembelajaran. Media yang digunakan harus dapat menampilkan tulisan, gambar, objek 3D dan animasi tentang pemintalan serat buatan.

Konsep yang dipilih sebagai media pembelajaran yaitu memaparkan materi tentang pengertian, pengenalan bagian-bagian, serta evaluasi berisi soal pemintalan serat buatan (kering dan basah). Konten-konten tersebut diselaraskan dengan objek tiga dimensi, video animasi, tata layout, pemilihan warna, dan tombol, serta background musik dan narasi. Media pembelajaran ini juga telah mendapatkan validasi dari Ahli Media yaitu Dosen, dan Ahli materi yaitu Guru mata pelajaran produktif teknik pemintalan serat buatan. Media pembelajaran ini dapat digunakan dengan mudah serta dapat menciptakan proses belajar mengajar yang menarik dan menyenangkan.

Penerapan augmented reality pada media pembelajaran berbasis Android ini dikembangkan dengan bantuan software Unity3D 2017, 3ds Max 2010, CorelDraw X8, dan WavePad Sound Editor. Berikut beberapa tampilan hasil perancangan aplikasi dilihat pada gambar 3-8:

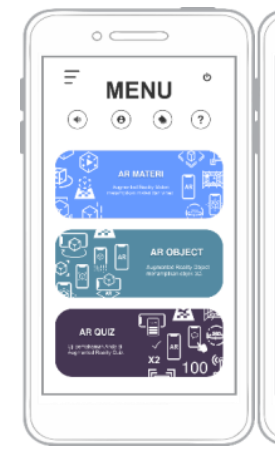

(3)

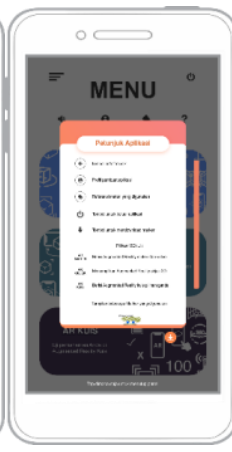

(4)

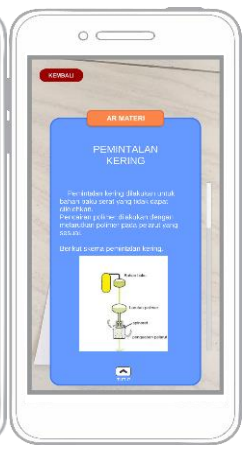

(5) 


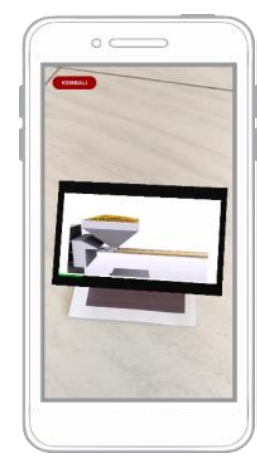

(6)

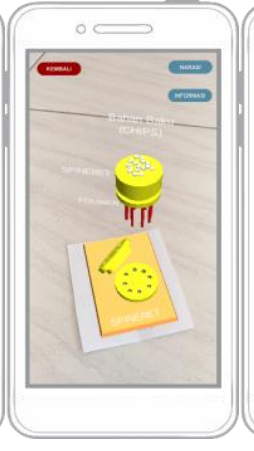

(7)

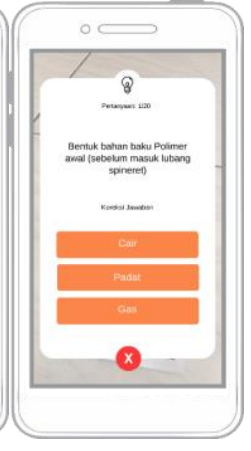

(8)

\section{Hasil Pengujian}

Data nilai uji coba user sebelum menggunakan aplikasi diperoleh data siswa yang belum mencapai KKM atau nilai $\leq 75$ sebanyak 17 siswa, dan yang sudah mencapai KKM sebanyak 3 siswa atau dapat dikatakan bahwa sebanyak $85 \%$ siswa belum mencapai nilai KKM, dan data uji coba user setelah menggunakan aplikasi diperoleh data siswa yang belum mencapai KKM atau nilai $\leq 75$ sebanyak 4 siswa, dan yang sudah mencapai KKM sebanyak 16 siswa atau dapat dikatakan bahwa setelah menggunakan produk siswa yang belum mencapai KKM mengalami penurunan yaitu dari $85 \%$ menjadi $20 \%$ saja.

Grafik pencapaian nilai KKM sebelum menggunakan produk

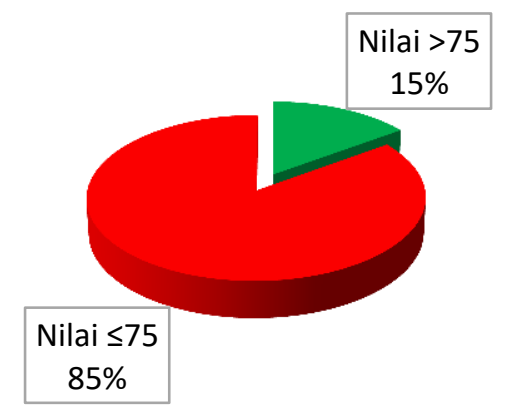

Grafik pencapaian nilai KKM sesudah menggunakan produk

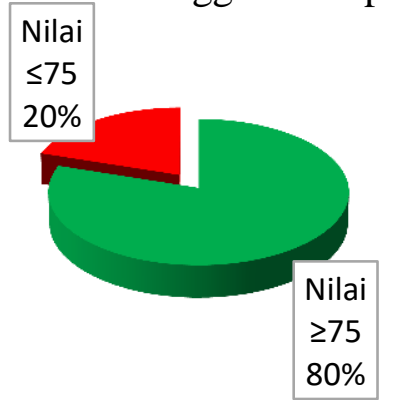

Gambar 9. Grafik Nilai Sebelum dan Sesudah Penggunaan Aplikasi

\section{SIMPULAN}

Kesimpulan yang dapat diambil berdasarkan data hasil penelitian perancangan, dan pengujian terhadap Penerapan Augmented Reality (AR) pada Media Pembelajaran Pemintalan Serat Buatan Berbasis Android untuk Siswa Kelas XI TPSB SMK Texmaco Semarang yaitu:

1. Perkembangan Teknologi Komunikasi dan Informasi dalam model serta pola pembelajaran sudah berkembang pesat, banyak menggunakan alat bantu seperti komputer, laptop, dan smartphone. Kurangnya keterampilan tenaga pendidik dalam pengelolaan pembelajaran dengan metode konvesional menyebabkan kurangnya minat belajar siswa, sehingga siswa sulit menerima materi pelajaran sehingga rendahnya capaian prestasi belajar.

2. Penerapanaugmented reality pada media pembelajaran berbasis Android merupakan salah satu strategi yang tepat dalam pembelajaran, jika dibandingkan dengan pembelajaran yang

JURNAL ILMIAH KOMPUTER GRAFIS Vol. 13, No. 1, Juli 2020: 1-8 
masih konvesional, pembelajaran dengan menggunakan alat bantu smartphone Android menjadi lebih interaktif.

3. Pembuatan aplikasi augmented reality dapat dilakukan melalui software Unity3D dan Vuforia.Permodelan 3D dibuat melalui software 3Ds Max 2010. Desain tombol dan layout dibuat dengan CorelDraw X8.Penambahan soal evaluasi dapat dilakukan melalui pengeditan pada script soal melalui software Monodevelopt.

4. Berdasarkan hasil pengujian validasi ahli media diperoleh nilai 3,2 termasuk kategori valid, hasil pengujian validasi ahli materi diperoleh nilai 3,6 termasuk kategori sangat valid, dan hasil pengujian validasi user diperoleh nilai 3,45 termasuk kategori sangat valid, sehingga dapat dikatakan bahwa media pembelajaran tersebut memenuhi kriteria nilai 3,26-4,00 termasuk dalam kategori layak, sehingga media ini dapat digunakan di SMK Texmaco Semarang.

5. Berdasarkan analisa pembahasan diperoleh data dari user sebelum menggunakan produk terdapat $85 \%$ siswa yang belum mencapai nilai KKM, dan data setelah menggunakan produk mengalami penurunan yaitu hanya sebanyak $20 \%$ yang belum mencapai KKM sehingga penelitian penerapan augmented realitypada media pembelajaran pemintalan serat buatan berbasis Android dapat dikatakan sangat efektif.

\section{DAFTAR PUSTAKA}

[1] Arsyad, A. (2013). Media Pembelajaran. Jakarta: Rajawali Pers.

[2] Ismayani, A. (2018). Cara Mudah Membuat Aplikasi Pembelajaran Berbasis Android dengan Thunkable . Jakarta: Elex Media Komputindo.

[3] Bambang Warsita. (2008). Teknologi Pembelajaran, Landasan dan Aplikasinya. Jakarta: Rineka Cipta.

[4] Joefrie, Y. Y., \& Anshori, Y. (2011). Teknologi Augmented Reality. "MEKTEK" TAHUN XIII NO. 3, 194.

[5] MADCOMS. (2018). Memanfaatkan Aplikasi Pendukung Android pada Sistem Operasi Windows . Yogyakarta: C. V ANDI OFFSET.

[6] Mulyadi. (2010). Membuat Aplikasi Untuk Android. Yogyakarta: Multimedia Center Publishing.

[7] Nizwardi, J., \& Ambiyar. (2016). Media dan Sumber Pembelajaran. Jakarta: Kencana.

[8] Jalinus, Nizwardi dan Ambiyar. 2016. Media \& Sumber Pembelajaran. Jakarta: Kencana.

[9] Pamoedji, A. K., Maryuni, \& Sanjaya, R. (2017). Mudah Membuat Game Augmented Reality (AR) dan Virtual Reality (VR) dengan Unity 3D. Jakarta: PT. Elex Media Komputindo.

[10] Pramono, A. (2013). Media Pendukung Pembelajaran Rumah Adat Indonesia Menggunakan Augmented Reality. ELTEK, Vol 11 Nomor 01, 124.

[11] Suryani, Nunuk. Ahmad Setiawan dan Aditin Putria. (2018). Media Pembelajaran Inovatif dan Pengembangannya. Bandung: Remaja Rosdakarya.

[12] Sugiyono. (2017). Metode Penelitian Pendidikan Pendidikan (Pendidikan Kuantitatif, Kualitatif, dan $R \& D)$ ). Bandung. Alfabeta. 